UDC 331.5:35:338

JEL Classification: L26, L59, 020, 050

http://doi.org/10.21272/mmi.2019.1-12

\author{
Abeer A. Mahrous, \\ Ph.D., Professor, Cairo University, Egypt

\section{FEMALE ENTREPRENEURSHIP IN EGYPT: NEW THEORETICAL AND PUBLIC POLICY} \\ IMPLICATIONS
}

\begin{abstract}
This paper is a report that aims to review research and reports on female entrepreneurship in order to guide and inform academics and public policy agencies about the opportunities and challenges surrounding female entrepreneurship in emerging markets such as Egypt. The female entrepreneurship discourse thus far highlights the need for further studies to advance the understanding of female entrepreneurship phenomenon. Therefore, this paper is one of the few research discussing female self-employment and entrepreneurial choices in Egypt. It also aims at synthesizing the previous literature and technical reports on female entrepreneurship to explore the challenges facing female entrepreneurs in general and in Egypt in specific. The paper builds on the institutional theory to delineate the operand and operant resources necessary to boost female entrepreneurship in emerging markets. The research implications should assist stakeholders to perceive the role of entrepreneurial marketing education in enhancing entrepreneurial success and solve the controversial role of the institutional environment in constraining female entrepreneurship. Finally, the paper will discuss future research opportunities and public policy implications for female entrepreneurship in Egypt. The paper is organized as follows. First, an introduction about the female entrepreneurship phenomenon in Egypt and the Arab and countries are introduced. Then, the second section discusses what female entrepreneurship means and the current status of the female-owned and managed organizations in Egypt. Next, a synthesis of the extant literature on female entrepreneurship is provided to explicate the drivers of female entrepreneurship success. Finally, concluding remarks about the future of female entrepreneurship studies and public policy implications are presented.
\end{abstract}

Keywords: entrepreneurship, female entrepreneurs, access to finance Egypt, institutional environment, MENA region, start-ups.

Introduction. If entrepreneurship will probably contribute to economic development and social inclusion, it is important that both female and male are totally represented among entrepreneurs. Nevertheless, the participation percentage of the female in business is still below the world average of $30 \%$ and is growing slowly (www.egypt-business.com). Actually, the growing trend of female entrepreneurship will help in enhancing the economic growth on the national level. Furthermore, female entrepreneurship will assist in bridging the unemployment gap that reached 24\% in Egypt in 2016, not only by creating more jobs but also by enhancing the social development of females in Egypt which will indirectly affect the economic development of the nation (Egypt Network for Integrated Development, 2017).

Recently, a new quite revolution is taking place in Egypt (Egypt's, 2017). Female entrepreneurship is widely evident in the Egyptian market. Moreover, many female entrepreneurs have taken entrepreneurship to new levels that have not been witnessed before by Egyptian entrepreneurship. The rate of female owned and/or managed enterprises have been unprecedentedly rising since 2011 (Egypt's, 2017). Furthermore, despite that the percentage of female entrepreneurs to all Egyptian entrepreneurs has increased from 3\% in 2010 to 10\% (Egypt Network for Integrated Development, 2017), it still has not reached the desired level. Figure 1 shows that the numbers of Egyptian women entrepreneur are ranked in eighth place among the top 10 African countries female entrepreneurs. Many entrepreneurship advocates think that female entrepreneurship will increase as the start-ups' ecosystems in Egypt becomes more developed.

Nevertheless, female entrepreneurs are faced by many challenges such as funding opportunities and the cultural expectations about the role of women in society. These challenges are not limited to emerging

Cite as: Mahrous, A. A. (2019). Female Entrepreneurship in Egypt: New Theoretical and Public Policy Implications. Marketing and Management of Innovations, 1, 151-160. http://doi.org/10.21272/mmi.2019.1-12 
markets and underdeveloped countries, in fact, there are many shreds of evidence about their presence in many developed markets as well, but maybe with a less magnitude (Adam et al., 2017).

\section{Female African \\ Entrepreneurship}

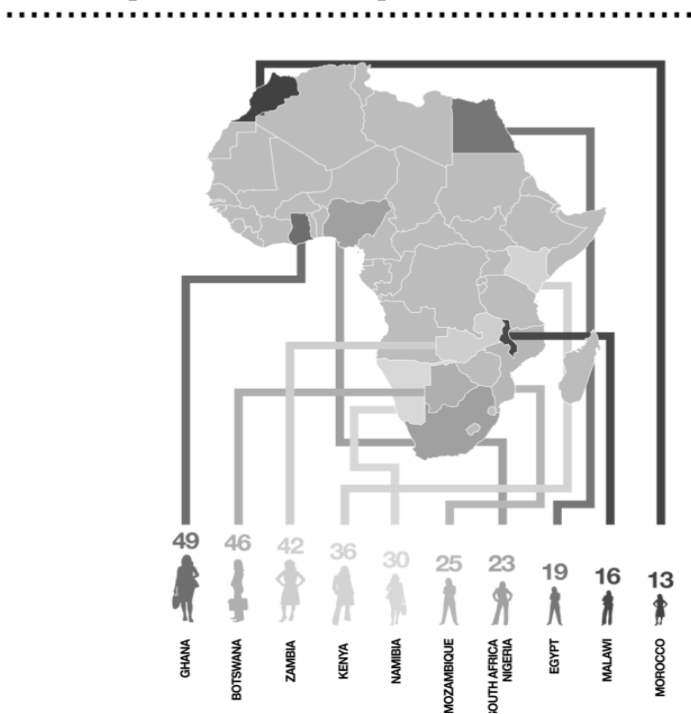

Figure 1. Female African Entrepreneurship

Source: Female African Entrepreneurship (2018).

The results of researches in female entrepreneurship are critical because it advances the knowledge about human behaviour and entrepreneurship. It also shed the light not only on the role of women in business environments and the magnitude of their participation in economic development, job creation, and labour market dynamics among other significant national economic indicators (Minniti \& Naudé, 2010).

Nevertheless, there is paucity of in-depth studies discussing female entrepreneurship in the MENA (Middle East and North African countries) region; there is a lack of quantitative research, comprehensive case studies or reliable statistics about female entrepreneurship in the MENA region to guide public policies aiming to enhance female entrepreneurship in these regions (Hattab, 2012).

The discussion thus far highlights the need for further studies to advance the understanding of female entrepreneurship development and advancements. Therefore, this paper is one of the few researchers (e.g. Adam et al., 2017; Hattab, 2012) discussing female entrepreneurs in Egypt. The purpose of this paper is to shed the light on female entrepreneurship in Egypt, a less researched area in the extant literature (Khattab and Mahrous, 2016; Mahrous and Genedy, 2018; Gupta et al. 2018; Mahrous, 2013; Mohsen et al. 2018; Shazly and Mahrous, 2017; Marzouk and Mahrous, 2017; Mahrous and Kotb, 2014). It also aims at synthesizing the previous literature on female entrepreneurship to explore the drivers of entrepreneurship success and suggest the capabilities that need attention from interested scholars in the EM arena. The paper will discuss future research opportunities and public policy implications for female entrepreneurship in Egypt.

The paper is organized as follows. The second section analyzes female entrepreneurship in Egypt indepth. Then, a synthesis of the extant literature is provided to explicate the drivers of female 
entrepreneurship success. Finally, concluding remarks about the future of female entrepreneurship studies and public policy implications are presented.

Literature Review. The definition of entrepreneurship has never been differentiated on the basis of gender and hence could be extended to female entrepreneurs without any restrictions. However, female entrepreneurship usually refers to the process where female organize all the factors of production, undertake risks, and produce products or offer specific service to others (Women Entrepreneurship: A Profile (2018)).

Small-scale ventures are important venues for female entrepreneurship especially in the leastdeveloped economies (Caniels et al., 2006). In this respect, SMEs provide a good starting point for the mobilization of women's talent, while at the same time SMEs can provide an avenue for the testing and development of women's entrepreneurial ability thus, SMEs do have an important role to play in promoting women empowerment in developing countries, which in these days is among important targets of the millennium development goals (Tambunan, 2011).

The interest and support to female entrepreneurship in Egypt were grounded on many economic, social and political factors. The role and experience of female entrepreneurship in developing countries and worldwide started due to the rise of 'Female-Headed Households' (household where the sole income producer is a female). In addition, the social will and political interest to support the vulnerable groups in societies such as women and minorities also paved the way towards the rise of female entrepreneurship in Egypt and worldwide. Furthermore, the interest in female entrepreneurship was grounded on the findings of the research in developing world showing that the impact of female entrepreneurship is better than male entrepreneurship in terms of household welfare because women tend to spend more on health, education and nutrition than men (Nichter \& Goldmark, 2009).

Moreover, female-owned businesses and start-ups tend to employ more women than do male headed businesses (Adam et al., 2017). Especially, in developing countries, extended family or other women are the only or major social network the females know and hence can rely on due to cultural taboos. From a different perspective, studies also showed that the differences in socioeconomic characteristics between female and male affect their businesses profile. For example, male-owned businesses are more profitable than female-owned businesses.

The motivations behind female entrepreneurship in Egypt usually centres around taking responsibility for their own destiny, they want to pursue their passions, make a change. But, not all female entrepreneurs start a business because they want to make a difference or become financially and socially independent. Some of them have been forced to start a business because they could not find a job and they were in need of financial support for themselves or for their families.

The entrepreneurial decision of Female entrepreneurs in Egypt like their counterparts in other developing (e.g. Morocco, Tunis, Lebanon, Argentina, Mexico) and developed countries is affected by many socioeconomic factors. For example, females who want to have more control over their time and income are more inclined to start a business than to find a job. This explains the findings of Maloney (2004), which indicated that women who are married and have children are more inclined to start a business than wage labour. In addition, married women are also more likely to quit a business voluntarily if they faced business-family conflicts (Justo \& DeTienne, 2008).

In addition, the gender role expectations in Egyptian society are a major effect on female entrepreneurship decision. In a male-dominated society, many women think that they should focus more on family than career and believe that professional success conflicts with taking care of their families. These household responsibilities inhibit women's participation in the formal economy (Tambunan, 2011), as family and social obligations make multiple demands on their time and thus hinder their full participation in developing their business. Women's business activities are often a supplement to family income, 
undertaken at home on a part-time basis as and when household tasks allow. Family responsibilities could also make women relatively risk-averse, which discourage innovative behaviour (Caniels et al., 2006).

Moreover, other reasons that compelled females to start a business in order to earn money are the unavailability or limitedness of governmental jobs, and the undesirability of women in the private sector because of the fear that women's family priorities will not enable them to provide full interest and attention in the workplace.

However, in Egypt, a country that witnessed waves of exceptional female political leaders and social movement advocates since the dawn of time, a new wave of women is rising and shattering stereotypes and selling glasses and creating unprecedented business models in the business environment arena in the local market and abroad. These women saw a market gap or wanted to pursue their passion. These female entrepreneurs have motivations to grow, to achieve, and to be more successful in an expanded marketplace despite the challenges and obstacles that hinder their development. Table 1 provides prominent examples of contemporary Egyptian female entrepreneurs' brands.

Table 1. Prominent Examples of Egyptian Female Entrepreneurship Brands

\begin{tabular}{|c|c|c|}
\hline Brand Name & Industry & Business Model \\
\hline $\begin{array}{c}\text { Reform } \\
\text { Studios }\end{array}$ & Furniture & $\begin{array}{c}\text { Reusing plastic products and transforming them into } \\
\text { furniture }\end{array}$ \\
\hline Handover & $\begin{array}{c}\text { Housing } \\
\text { Developments }\end{array}$ & Sustainable housing solutions to Cairo homelessness \\
\hline Azza Fahmy & $\begin{array}{c}\text { Jewellery \& } \\
\text { Accessories Design }\end{array}$ & $\begin{array}{c}\text { This brand shifted silver and semi-precious stones } \\
\text { accessories from low-perceived quality to high-street } \\
\text { artistic jewellery pieces. }\end{array}$ \\
\hline Events & Hospitality & $\begin{array}{c}\text { An international award-winning event management } \\
\text { mobile application }\end{array}$ \\
\hline Okhtein & $\begin{array}{c}\text { Fashion \& Accessories } \\
\text { Design }\end{array}$ & $\begin{array}{c}\text { Okhtein seeks to set new trends, promoting Egyptian } \\
\text { artistry as well as presenting new female bag designs } \\
\text { to the world1. }\end{array}$ \\
\hline Temraza & $\begin{array}{c}\text { Fashion \& Accessories } \\
\text { Design }\end{array}$ & $\begin{array}{c}\text { Providing unique and elegant designs that perfectly } \\
\text { sculpt and enhance a woman's silhouette using } \\
\text { glamorous details2. }\end{array}$ \\
\hline INJAZ Egypt & $\begin{array}{c}\text { Training and Human } \\
\text { Development }\end{array}$ & $\begin{array}{c}\text { A volunteer-based educational program to prepare } \\
\text { youth to establish start-ups and new ventures } 3 .\end{array}$ \\
\hline
\end{tabular}

Sources: developed by the author on the basis of (Okhtein, 2018; Temraza, 2018; Injaz, 2018).

There are a number of efforts in Egypt to improve the socio-economic environment for women entrepreneurs. The National Council for Women (NCW) has the authorization from the government to advance the status of Egyptian women by enhancing their social, economic and political status. Also, the Women Business Development Center (WBDC) operated under the supervision of the National Council for Women (NCW) offers technical, financial, and legal counselling to women at various stages of business development and growth, including administrative, research and marketing support to women seeking to start a business. Similarly, the Social Fund For Development (SFD) which is a major government body to support micro and small enterprises (MSE) development, has developed a strategy designed to enable and support the capacity of women entrepreneurs to benefit from loans and facilities offered by the Small Enterprise Development Organization (SEDO) and also places special emphasis on female-headed households and women's employment. And so forth female entrepreneurs depends upon any of these associations to face the obstacles in which some of the female sought help from the WBDC, obtain loans 
from the SFD, and/or immersed themselves in learning by taking courses and participating in international fairs and exhibitions and others may seek partners (Adam et al., 2017).

There are at least 22 businesswomen associations (BWAs) in the country offering networking, training, and other supports to the women entrepreneurs, however, these benefits reach only a small number of women and sometimes these associations suffer from limited resources and capacities. These (BWAs) do play an important role in promoting women's entrepreneurial activity and raising awareness of the needs and concerns of women in business in their communities. The study of female entrepreneurship has gone through a set of developmental phases. This section highlights the origin of female entrepreneurship studies, as well as the current state of the literature and where it's headed in the future.

The early studies of Female entrepreneurship focused on profiling entrepreneurs; what are the characteristics that separate entrepreneurs from other individuals (Greene et al, 2007). Also, some studies focused on (e.g. Birley et al., 1987; Holmquist \& Sundin, 1988) how female entrepreneurs are different from other entrepreneurs. Female Entrepreneurship studies were grounded on the feminist theories bases (Hurley, 1999; Greer \& Greene, 2003). In terms of entrepreneurial traits, Bennett and Dann (2000) noted that there are three personality traits that are common among female entrepreneurs which are the internal locus of control, independence/need for achievement and risk taking. Also, they noted that women are motivated to start a business to gain autonomy and control over their career. Zhang et al., (2009) study that aims at investigating the genetic influences and shared environmental factors in predicting the propensity of males and females to become entrepreneurs, their study pointed out that women have a natural strong impact and no social influence on their desires to become entrepreneurs.

Studies in the 1990s focused on the study of female's employment choices, (Goldin, 1990) and examined the impact of female entrepreneurship on the allocation of family resources, family decisions, employment opportunities perceptions, self-confidence and poverty, among others. In this era, the phenomenon of female entrepreneurship was well-perceived as an area of academic inquiry and a popular argument for the media and public policy agencies. In fact, the statistics and research results indicating that female entrepreneurs make fewer earnings and income than male entrepreneurs have given rise to a substantial body of literature investigating female's motivations and ambitions as entrepreneurs (Figure 2).

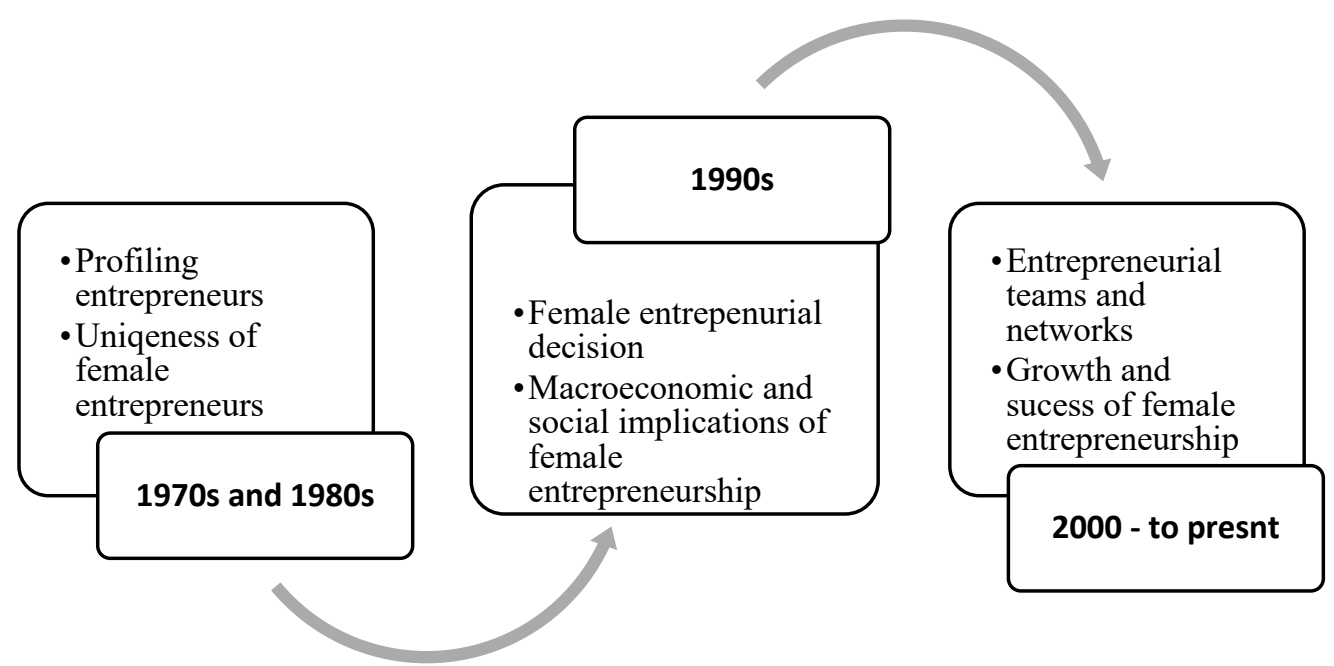

Figure 2. The Evolution of Female Entrepreneurship Research

Source: developed by the author on the basis of Adam et al., (2017). 
Minnit (2008) examined the variables associated with the female entrepreneurial decision. She found that the motivations of the entrepreneurial decision are the same for male and female and across countries, but the magnitude of the effect of these variables vary across gender and across countries. The gender gap in entrepreneurship activities is narrow in developing countries and wide in developed countries, perhaps because of fewer work opportunities in these countries and/or the need to support themselves and their families. Socio-economic characteristics have a weak effect but gender role, fear of failure and existence of opportunities are associated with gender differences in the entrepreneurial decision. Sullivan (1997) study that examines why rural females started businesses, how they define business success, and what from their family background and what resources helped them start and continue in business, his study found that female entrepreneurs are successful due to the support and encouragement from their family members, the ability to enjoy their job, and strong local community support. Elam and Terjesen (2010) argue that despite the attention given to explaining the gender gap in entrepreneurial activities across countries, less attention has been focused on the gender gap in start-up activities within the same country or countries with the same economic level. Specifically, they studied the culture and institutions such as the gender wage gap, female institution leadership, and public expenditures on children. They recommended further research on the influence of formal public policy institutions support on reducing the gender gap. Chirwa (2008) findings imply that female-owned enterprises tend to grow more rapidly in terms of employment than male-owned ones likewise. Similarly, Fuller-Love et al., (2006) study found that women entrepreneurs improve their performance through managerial skills and competencies they gained. In the late 1990s, research focused on examining entrepreneurial teams and networks (e.g. Aldrich et al, 2002; Greve \& Salaff, 2003). Also, topics such as the firm's performance and growth, management and leadership style, financial and human resources, and social entrepreneurship of female-owned businesses have been examined (e.g., Carter, 1997; Burke, 2002; Adam et al., 2017). Hampel-Milagrosa (2015) examined the impact of business regulation on decreasing the challenges facing women to start a business. In addition, Adam et al. (2017) studied the impact of entrepreneurial orientation and marketing capabilities on the competitive advantage of female-owned SMEs in Egypt.

Results. Despite female entrepreneurs' feelings of empowerment and excitement, there are also feelings of disappointment and doubt. This is perhaps because society, culture and business regulations are not always supportive of female entrepreneurship. Women-owned start-ups face several cultural, social, economic and regulatory barriers and resource constraints that inhibit their active participation in the entrepreneurial activity. Thus, female owned/managed SMEs enterprises should leverage their entrepreneurial and marketing capabilities in order to be able to confront such obstacles. To this end, this section aims at identifying and delineating the challenges facing female entrepreneurship in general and female entrepreneurs in Egypt in specific, in order to build on them to develop a framework for enhancing female entrepreneurship. Generally speaking, female entrepreneurs' face several challenges as depicted in Figure 3.

Small and medium enterprises (SMEs) are a major force for creating jobs and economic growth in emerging countries as evidenced by their contribution to economic diversification and private sector development (ILO, 2016). In particular, female SMEs in Egypt have less access to formal training in technical, business management, and entrepreneurial aspects also; they have fewer opportunities for business development services (BDS), and finance, in which all these factors and others inhibit their SMEs growth and survival. Thus, female SMEs should be able to achieve a competitive advantage in order to maintain and grow its market share in the industries where it competes.

In fact, Most female entrepreneurs had difficulties with financing, business registration and licensing processes, customs procedures, building permits, the high costs of importing, finding specialized 
information and expertise related to their businesses, and for some women, the problem was with achieving the right balance between managing the business and their household activities.

\section{Challenges of Female Entrepreneurship}

- Low of appropriate educational background.

- Lack of training opportunities for managing a business.

- Limited marketing and sales knowledge.

These constraints make it harder for women to understand and express their business problems and needs or write a business plan.

- Legal constraints in the form of more legal requirements to start a business by women.

- Cultural and religious beliefs may not favour or support establishing a business by a female.

- Lack of access to formal finance.

- Limited or no financial institutions.

- Loans to businesswomen are more costly than loans to businessmen because female businesses are considered riskier.

\section{Figure 3. Challenges of Female Entrepreneurship}

Source: Developed by the authors on the basis of Tambunan, 2011

For example, access and acquiring capital and other financial assets are more challenging for female entrepreneurs than male entrepreneurs in emerging markets (Estrin at al., 2019). Some banks consider loaning women-owned ventures riskier than loaning male-owned ventures. In addition, studies (Khairy, 2019; IFC, 2017) indicated that although one-third of all business ventures in Egypt are owned by females, they only access less than $10 \%$ of commercial bank finances. Studies suggest that womenowned ventures in Egypt have observable unmet financing needs. Therefore, there is a pressing need to overcome these financial challenges facing female entrepreneurs by simplifying bank requirements, developing specific interest rates, conducting training workshops to raise awareness and encouraging businesswomen to network and cooperate to leverage their financial resources. Accordingly, many initiatives on the local and international levels have been developed to encourage female entrepreneurs, especially in rural Egypt. For example, The World Bank introduced in 2012 a loaning program for femaleowned SMEs, especially in poor rural areas of Egypt. Also, some NGOs like the Association for the Development and Enhancement of Women and B'edeyah are helping to empower Egyptian female to start and finance their own business (www.egypt-business.com).

All these challenges impede productive investments of all kinds, so that small enterprises run by women tend to cluster in capital-scarce activities in saturated markets, with limited scope for innovation (Caniels et al., 2006). In this sense, the framework for supporting female entrepreneurship must be built around two pillars; the first is to create a cultural, social, and economic environment that is more favourable to the emergence of women as entrepreneurs, and the other is to ensure that women who already have their own enterprises have adequate access to the resources and supports needed for sustainability and growth that is, financing, technical and business management training, information, business networks, and technology.

Conclusion. The involvement of women as entrepreneurs and end-users in all stages of new service development is an issue that requires urgent attention (Caniels et al. 2006). Accordingly, the objective of this research is to investigate the female entrepreneurship phenomenon and challenges in order to guide theoretical research and public policies in Arab countries. This study argues conclusively for two main streams of implications from a managerial perspective for theory and public policy with regard to female entrepreneurship (Mahrous, 2013; Mahrous, 2016). 
The explanation for the behaviour of female-owned business ventures in terms of characteristics, motivations and growth rates, is complex and multifaceted. Despite the increasing body of research, female entrepreneurship is understudied; there is a need for more research on female entrepreneurship. The review of the literature on female entrepreneurship focused on examining female entrepreneurship in terms of their demographics, their business profile and their entrepreneurial, marketing and technological orientation. Nevertheless, there is still a lot to be done regarding explaining female entrepreneurship among countries and between developed and non-developed countries. There is a need for cross-cultural studies and cross-sectional studies in order to be able to develop a theory of female entrepreneurship. Understanding the similarities and differences across individuals and countries are significant steps toward understanding female entrepreneurship, its antecedents and potential implications for public policy. In fact, the rising number of initiatives aimed at fostering entrepreneurship in emerging markets, and particularly at empowering females in the process, should take such similarities and differences into concern.

Furthermore, research, as well as public policy institutions, should provide reliable research methods and statistics about a number of pressing issues to guide public policies on female entrepreneurship such as what is the female entrepreneurship percentage in Egypt? What institutions support or hinder entrepreneurial decision in general and female entrepreneurial decision in specific? What are the economic implications of female entrepreneurship in Egypt?

Additionally, an area that requires immense attention from public policy agencies or regulators is the measures of the favourable institutional environment. In this regard, a mix of qualitative and quantitative measures on the level of traditions and beliefs about females-owned businesses should complement the regular measures of the business environment and regulations. The inclusion of such qualitative measures of gender discrimination at the level of national regulation measure (e.g., 'DBI', World Bank Doing Business Indicator) will provide a better and broader perspective about how favourable the institutional environment is toward female entrepreneurship (Hampel-Milagrosa, 2015).

Finally, as a way forward, public policy agencies should focus on creating effective venues to provide advisory services to financial institutions to build successful business lines in the female's bank customer segment. This would have immense support for women-owned enterprises in Egypt. In addition, there should be national training programs to provide customized training for female current or prospective entrepreneurs in business planning and management, and financial literacy. There also should be entrepreneurship NGOs and associations to facilitate networking and mentoring for female entrepreneurs to support market expansion and business growth. Finally, banks association in the MENA region should focus on encouraging banks to launch specific banking products for females to overcome the problems related to difficulties in access to capital and managing businesses in the MENA region.

\section{References}

Adam, S., Mahrous, A. A., \& Kortam, W. (2017). The relationship between entrepreneurial orientation, marketing innovation and competitive marketing advantage of female entrepreneurs in Egypt. International Journal of Technology Management \& Sustainable Development, 16(2), 157-174

Aldrich, H.E., Carter, N. \& Ruef, M. (2002). With very little help from their friends: Gender and relational composition of nascent entrepreneurs' startup teams. Frontiers of Entrepreneurship Research 2002. Babson Park, MA: Babson College.

Bennett, R., \& Dann, S. (2000). The changing experience of Australian female entrepreneurs. Gender, work \& organization, $7(2), 75-83$.

Birley, S., Moss, C. \& Saunders, P. (1987) Do women entrepreneurs require different training? American Journal of Small Business, 12 (1): 27-35.

Burke, A.E. (2002). Self-employment wealth and job creation: The roles of gender, non-pecuniary motivation and entrepreneurial ability. Small Business Economics, 19 (3): 255-270. 
Carter, N.M. \& Allen, K.R. (1997). Size determinants of women-owned businesses: Choice or barriers to resources? Entrepreneurship and Regional Development, 9 (3): 211-220.

Chirwa E.W., (2008). «Effects of gender on the performance of micro and small enterprises in Malawi», Development Southern Africa, 25(3)

Egypt Network for Integrated Development, (2017). Retrieved at http://enid.org.eg/ Accessed at February 05, 2018

Egypt's New Quiet Revolution: Female Entrepreneurship. (2017). Retrieved at www.because.bz/.../egypt's-new-quietrevolution-female-entrepreneu..., Accessed at August 27, 2018

Elam, A., \& Terjesen, S. (2010). Gendered institutions and cross-national patterns of business creation for men and women. The European Journal of Development Research, 22(3):331-348

Estrin, S., Mickiewicz, T., Stephan, U., \& Wright, M. (2019). Entrepreneurship in Emerging Markets. The Oxford Handbook of Management in Emerging Markets, 457.

Female African Entrepreneurship, Afrographique, retrieved at (2018). http://afrographique.tumblr.com/, Accessed at October 12,2018

Female-Entrepreneurship-in-the-Middle-East. (2018). Retrieved at: www.egypt-business.com/News/details/1704-FemaleEntrepreneurship-in-the-Middle-East/83478. Accessed March 15, 2018

Fuller-Love, N., Lim, L., \& Akehurst, G. (2006). Guest editorial: Female and ethnic minority entrepreneurship. The International Entrepreneurship and Management Journal, 2(4), 429-439

Goldin, C. (1990). Understanding the Gender Gap: An Economic History of American Women. New York: Oxford University Press.

Greer, M.J. and Greene, P.G. (2003). Feminist theory and the study of entrepreneurship. In: J.E. Butler (ed.) New Perspectives on Women Entrepreneurs. Greenwich, CT: Information Age Publishing, 1-24.

Greve, A. and Salaff, J.W. (2003). Social networks and entrepreneurship. Entrepreneurship Theory and Practice, 28(1): 1-22.

Gupta, M., Uz, I., Esmaeilzadeh, P., Noboa, F., Mahrous, A. A., Kim, E., ... \& Peters, A. (2018). Do cultural norms affect social network behavior inappropriateness? A global study. Journal of Business Research, 85, 10-22.

Hampel-Milagrosa, A., Loewe, M., \& Reeg, C. (2015). The entrepreneur makes a difference: Evidence on MSE upgrading factors from Egypt, India, and the Philippines. World Development, 66: 118-130

Hattab, H. (2012). Towards understanding female entrepreneurship in Middle Eastern and North African countries: A crosscountry comparison of female entrepreneurship. Education, Business and Society: Contemporary Middle Eastern Issues, 5(3):171186.

Hurley, A. (1999). Incorporating feminist theories into sociological theories of entrepreneurship. Women in Management Review, 14: 54-62.

IFC (2017). Unlocking the potential of women entrepreneurs in Egypt, Retrieved at www.ifc.org/wps/wcm/connect/news_ext_content/ifc_external_corporate_site. Accessed at February 5, 2018

ILO (2016). Women's entrepreneurship development assessment, International Labor Organization, ILO DWT for North Africa and ILO Country Offices for Egypt and Eritrea. Cairo: ILO, 2016.

Injaz Egypt. (2018). Retrieved from: http://www.injaz-egypt.org

Khairy, N. A. (2019). Women-owned MSMEs and Financial Inclusion in Egypt. Retrieved at http://dar.aucegypt.edu/bitstream/handle/10526/5628/FINAL\%20THESIS-12-1\%20NK.pdf?sequence=1 (Last accessed 27 July 2018)

Khattab, L., \& Mahrous, A. A. (2016). Revisiting online banner advertising recall: An experimental study of the factors affecting banner recall in an Arab context. Journal of Arab \& Muslim Media Research, 9(2), 237-249.

Mahrous, A. A. (2013). Social Media Marketing: Prospects for Marketing Theory and Practice on the Social Web. In E-Marketing in Developed and Developing Countries: Emerging Practices (pp. 56-68). IGI Global.

Mahrous, A. A. (2013). Social Media Marketing: Prospects for Marketing Theory and Practice on the Social Web. In E-Marketing in Developed and Developing Countries: Emerging Practices (pp. 56-68). IGI Global.

Mahrous, A. A. (2016). Implications of the use of social media for pre-purchase information searches for automobiles. International Journal of Technology Marketing, 11(3), 254-275.

Mahrous, A. A., \& Genedy, M. A. (2018). Connecting the dots: The relationship among intra-organizational environment, entrepreneurial orientation, market orientation and organizational performance. Journal of Entrepreneurship in Emerging Economies.

Mahrous, A. A., \& Hassan, S. S. (2017). Achieving superior customer experience: An investigation of multichannel choices in the travel and tourism industry of an emerging market. Journal of Travel Research, 56(8), 1049-1064.

Mahrous, A. A., \& Kotb, A. (2014, June). Antecedents of virtual communities participation and their purchasing behavior consequence. In Proceedings of the 4th Conference of the International Network of Business \& Management Journals (INBAM), Management Decision, Barcelona, 25-27 June

Marzouk, O., \& Mahrous, A. (2017). An exploratory study on energy and water sustainable consumption behaviors of rural consumers in Egypt.

Minniti, M., \& Naudé, W. (2010). What do we know about the patterns and determinants of female entrepreneurship across countries? 
Mohsen, Y., Hussein, H. M., \& Mahrous, A. A. (2018). Perceived service value, customer engagement and brand loyalty in health care centres in Egypt.

Okhtein. (2018). Retrieved from: https://okhtein.com

Shazly, R., \& Mahrous, A. (2017). A qualitative investigation of the factors associated with attitude toward causal-related marketing campaigns in services industries in Egypt.

Tambunan, T. (2011). Development of small and medium enterprises in a developing country: The Indonesian case. Journal of Enterprising Communities: People and Places in the Global Economy, 5(1): 68-82

Temraza. (2018). Retrieved from: https://temraza.com/about/

Women Entrepreneurship:A Profile (2018), Retrieved At http://Shodhganga.Inflibnet.Ac.In/ Bitstream/10603/6775/ 12/12 Chapter\%201.Pdf. Accessed at March 27, 2018

A. A. Maхроус, Ph.D., профресор, Каїрський університет (Єәипет).

Жіноче підприємництво в Єгипті: нові теоретичні аспекти та наслідки для державної політики

У рамках даного дослідження автором проаналізовано особливості та бар'єри розвитку жіночого підприємництва з метою інформування академічної спільноти та державних установ щодо перспектив та викликів, які постають перед жінками-підприємиями на ринках країн, що розвиваються, зокрема, таких як Єзипет. Особливості культури та традиції певних країн обумовлюють появу низки дискусій щодо френомену жіночого підприємництва, що у свою чергу обумовлює актуальність дослідження даної проблематики, та зумовлює необхідність подальшого аналізу специфріки жіночого підприємництва з урахуванням особливостей функціонування країн, що розвиваються. Автором наголощено, що наявні наукові доробки щодо розвитку жіночого підприємництва не враховують особливості самозайнятості жінок в Єаипті, а також фракторів, що впливають на жінок при прийнятті рішень щодо розвитку своєї підприємницької діяльності. Автором проведено систематизацію літературних джерел та практичних підходів щодо вивчення проблем розвитку жіночого підприємництва в цілому, та в Єәипті зокрема. На основі аналізу інституційних особливостей виокремлено необхідні ресурси та набір кваліфікацій, що сприятимуть розвитку жіночого підприємництва на ринках, що розвиваються. Автором проведено дослідження в наступній логічній послідовності - визначено та досліджено поняття фенномену жіночого підприємництва в Єгипті та арабських країнах, проведено аналіз поточного стану організацій, якими керують чи володіють жінки в Єгипті. За результатами проведених теоретичних досліджень автором визначено та охарактеризовано основні фрактори успіху жіночого підприємництва. у статті визначено, що поширення результатів дослідження серед основних стейкхолдерів сприятиме усвідомленню ролі маркетингової освіти у ссрері підприємництва в контексті підвищення рівня його успішності та визнанню суперечливості інституційного середовища, що формує відповідні бар'єри для жінок-підприємців. В результаті роботи автором визначено напрями для подальших теоретичних досліджень, перспектив розробки та імплементації державних механізмів регулювання жіночого підприємництва в Єгипті. стартап.

Ключові слова: підприємництво, жінки-підприємці, доступ до фінансування в Єгипті, інституційне середовище, MENA,

Manuscript received: 25.10 .18

(C) The author(s) 2019. This article is published with open access at Sumy State University. 